\title{
The Role of Catholic Based Organisations in Addressing Livelihood Challenges of the Rural Refugee Youth Population in the Context of Forced Migration in Zambia
}

\author{
Nelly Mwale \\ ORCID iD: https://orcid.org/0000-0002-4556-9239
}

\begin{abstract}
Despite the engagement of different stakeholders to address the livelihood challenges faced by refugee youth in Zambia, the public sphere continues to be dominated by discourses of challenges among the rural refugee youth population. This article interrogates the role of two selected Catholic based organisations in addressing the challenges encountered by the refugee youth in the context of forced migration in Zambia. It employs religious capital as a lens and draws on insights from an interpretive case study that employed content analysis of archival material and media representations of the work of Catholic based organisations in the rural refugee youth population. The article shows that the role of the Catholic based organisations included the provision of pastoral care, youth empowerment initiatives, social integration interventions and advocacy as driven by their religious capital. This article therefore concludes that the results of the interpretive case study in the Zambian context pointed to how religion, delivered through Catholic based organisations could prove resourceful in addressing the livelihood challenges among the rural refugee youth population.
\end{abstract}

Keywords: migration, refugee, youth, Catholic Based Organisations, religious capital

\section{Introduction}

Religion based organisations have played different roles to mitigate the effects of forced migration on migrants in different contexts. In the Zambian context, 
Catholic based organisations are present throughout the country, working with refugee populations. Despite multi-sectorial efforts to address the challenges faced by refugee youth in Zambia, the discourses of the refugee youth population in the public sphere have continued to be associated with challenges they were facing in the context of forced migration. The article therefore addresses the question of what roles the Catholic based organisations have played in addressing the livelihood challenges faced by the refugee youth (aged between 16 and 35 years) in rural Zambia.

This article focuses on the role religion plays in forced migration, taking cognisance of the revelation that religion has long been seen as instrumental in mitigating the effects of the migration crises. For example, religion was instrumental in addressing the concerns of the refugee populations in South Africa, as highlighted by Chisale (2016) who noted the contributions of Bishop Paul Verryn in providing pastoral care to refugee children. In a study on one Pentecostal migrant Church in Johannesburg, South Africa, Nzayabino (2010) noted that, religion played a role in migrants' spiritual, social and economic lives. Sommers (2001) with reference to the Burundi refugee youth in Tanzania, further concluded that refugees tended to become more religious in their host countries than they were in their home countries while Hagan and Ebaugh (2003), showed migrants' use of religion as a tool for resilience, to cope with the challenges of migration. Nzayabino (2010) also affirmed religion as a coping strategy, that was increasingly taking shape within refugee communities, especially in Africa. Settler and Mpofu (2017) who from their South African study, dealt with the response of the Church in migrant communities and the failure of the state to adequately respond to the migrant communities, have focused on the response of religion to forced migration. Despite the growing scholarly engagement on religion and forced migration, there is limited scholarly work on religion and forced migration in Zambia. This article therefore seeks to contribute to the body of knowledge on religion and forced migration in Zambia, using the example of Catholic based organisations. Unlike focusing on the Church as an institution, this article dwells on the Catholic based organisations specifically, as an arm in the mission of the Church working with the refugee youth population in Zambia.

The Catholic based organisations were of interest because Zambia is predominately Christian, and the Catholic Church has historically played an instrumental role in advancing development of the country (Mwale 2013) and general refugee welfare. To this end, the work of Caritas Zambia and the Jesuit 
Refugee Service will be used as examples of Catholic based organisations. For example, having played a prominent role in the 2016 xenophobic attacks against Rwandan refugees and other nationals (Mwale \& Chita 2017), it became imperative to understand how the Catholic based organisations had shaped the discourses of forced migration beyond the 2016 incident especially since 'migration could also be viewed through a theological prism' (Aymer 2015: 1).

The article was also driven by lapses in migration studies in the Zambian context. In this regard, migration studies and in particular, refugeerelated studies (Carmona 2010; Nyamazana et al. 2017) were devoid of an engagement foregrounded in religion as more often than not, religion-related activities were merely referred to in passing. For example, Carmona (2010) addressed the economic challenges that the urban youth refugee population faced in Zambia, especially those relating to restrictions on freedom of movement and the right to work. Another study revealed that the challenges were similarly related to regulations related to the right to work and freedom of movement, as well as discrimination, harassment and security attacks, lack of capital and expensive rent (Nyamazana et al. 2017). The encampment policy (contained in the Refugee Control Act of 1970 (Government of the Republic of Zambia 1970) that restricts the refugees' rights to exercise freedom of movement and residence) adversely affected young refugees, often located in urban areas, who were keen to advance their qualifications through tertiary and vocational training (Nyamazana et al. 2017). Donger et al. (2017) also revealed that socio-economic challenges were linked to refugees' access to education, birth registration and increasing statelessness, the detention of asylum seekers, and various barriers to work. The above cited studies (Carmona 2010; Nyamazana et al. 2017; Donger et al. 2017) while being insightful merely pointed to Faith Based Organisations as partners in addressing the concerns of the refugee population in Zambia. They were also largely grounded in economics, legal and procedural safeguards and freedom of movement and therefore devoid of the religion dimension. Hence, this article interrogates the role of Catholic based organisations in addressing the livelihood challenges faced by the refugee youth population in rural Zambia.

The article specifically focuses on the work of Catholic based organisations among the refugee youth in rural areas largely because the discourses of refugee youth were preoccupied by urban youth. For example, Donger et al. (2017) confirmed that several studies had documented the challenges faced by 
the urban refugee population in Zambia, especially those arising from the restrictions on freedom of movement. Carmona (2010) also observed that many urban refugee youth resorted to informal markets where they were exposed to exploitative working conditions owing to work restrictions. There was therefore a need to capture the discourses of the work of the Catholic based organisations so as to understand the rural dimension of the refugee population in Zambia. The article proceeds with defining key concepts and providing brief perspectives on the analytical framework and methods before discussing the role of the Catholic based organisations in addressing the livelihood challenges faced by the refugee youth population of rural Zambia.

\section{Defining Refugee, Forced Migration and Religion}

The use of the term refugee relates to:

... a person who owing to a well-founded fear of being persecuted for reasons of religion, nationality, membership of a particular social group or political opinion, is outside the country of her/his nationality and is unable, or owing to such fear, is unwilling to avail her/himself of the protection of that country or who, not having a nationality and being outside the country of her/his former habitual residence as a result of such events, is unable or, owing to such fear, is unwilling to return to it ... (UN Convention 1951, article 1A[2]).

The term is also informed by the 1969 refugee convention of the African Union, formerly the Organization of African Unity (OAU) (UNCHR 2019). The African Union extended the definition to include a person who; owing to external aggression, occupation, foreign domination or events seriously disturbing or disrupting public order in either a part or the whole of his or her country of origin or nationality, is compelled to leave his or her place of habitual residence in order to seek refuge elsewhere (UNCHR 2019). Given the numerous categories of refugees, the study focuses only on the work of the Catholic based organisations with the refugee youth (aged 16 to 35 years).

The concept of refugee is also closely tied to forced migration. As observed by Becker and Ferrara (2019:1), forced migration may have consequences which affect the receiving population, the migrants themselves and the sending populations. Given that forced migration is more likely to be 
a distinct experience for the migrants themselves, it is associated with numerous challenges such as losing physical assets (Becker \& Ferrara 2019), and long-lasting effects on their livelihoods (Carmona 2010).

The understanding of the concept of religion is largely informed by Ter Haar and Busuttil (2005: 2) who distinguish four components of religion which constitute religious resources namely, religious ideas (the 'content' of faith or what people actually believe), religious practices (ritual behaviour), religious organisation (the formation and function of the religious community), and religious or spiritual experiences (psychic attitudes and subjective experiences of inner transformation). As such, religion relates to the belief in the existence of an invisible world, distinct but not separate from the visible one which is home to spiritual beings that are deemed to have effective powers over the material worlds (Ellis \& Ter Haar 2006: 14). The link between religion and forced migration was viewed through the work of the Catholic based organisations because as Ter Haar and Ellis (2006) note, religious resources can produce knowledge that could be beneficial to a community for development purposes.

\section{Analytical Framework}

The article situates the role of Catholic based organisations in addressing the livelihood challenges faced by rural refugee youth in religious capital theories. The notion of religious capital (Verter 2003) was linked to migration as an explanatory tool in the quest to understand the interconnectedness of religion and migration, through the example of the role of Catholic based organisations in addressing the livelihood challenges among refugee youth. The article largely drew on the ideas of Bradford Verter (2003). Verter (2003) offered a model of religious capital that extended Bourdieu's (1986) general theory which posited that capital existed under three fundamental species: economic capital, cultural capital, and social capital, with religious capital forming part of cultural capital. Verter (2003) noted that 'spiritual capital', included religious knowledge, competencies, and preferences as 'positional goods' within a competitive symbolic economy. In this regard, religious capital relates to the skills and experiences specific to one's religion, including religious knowledge, familiarity with ritual and doctrine and friendliness with fellow worshippers (Innanaccone 1990). This perspective takes the view that capital also exists in symbolic forms (Verter 2003). In addition to Collet (2011) who 
examined varying influences of religious capital among Iraqi Christian refugee students, Adogame and Weissköppel (2005), Adogame (2013), Hanciles (2008), and Schreiter (2009) drew conclusions on the role and significance of religion on the migrants from a religious capital perspective, providing grounds for understanding the interaction between religion and forced migration.

The article shifts the attention from the migrants to religious based organisations (Catholic based organisations) by applying religious capital to their engagement in responding to forced migration among the refugee youth population. Religious capital is deemed significant for understanding the work of Catholic based organisations, given that religion is not monolithic in nature. As such, disaggregating religious systems into component parts was deemed valuable because of the understanding that religious components can be carefully described in a particular time and place and situated in a context. For example, when religion is described as being composed of ideas, practices, organisation and experiences (Ter Haar \& Busutil 2005), these parts become the capital that can be used to understand religion's engagement with public life. As such, religious capital has offered a useful direction for understanding religion's engagement in forced migration by linking the role of Catholic based organisations in addressing the livelihood challenges among the refugee population to their theology. As can be deduced, the notion of religious capital also resonates with the notion that religious resources are viewed as being composed of religious ideas, practices, organisations and experiences.

\section{Method}

The study is informed by the content analysis of discourses on the work of Catholic based organisations in addressing the livelihood challenges faced by the refugee youth population in rural Zambia in the media. The media was used as a mirror because as Hoover (2012) remarked, it was a window through which society could be understood in the $21^{\text {st }}$ century.

An interpretive case study method was employed because of the nature of the study. As advanced by Myers (2009) and Mouton (2001), case study research is appropriate for descriptive and exploratory studies. Consistent with the purposive selection of the phenomena and case in case study research (Merriam 2009; Creswell 2007), the Catholic based organisations were purposively chosen based on historical facts - the Catholic Church had played a public role in refugee-related matters in the country (Komakoma 2003; 
Mwale \& Chita 2017). Therefore, the Catholic based organisations were chosen based on their relevance to the aim of the study.

The specific Catholic based organisations that were chosen were the Jesuit Refugee Service (JRS) and Caritas Zambia. The JRS is an international Catholic organisation that was founded in 1980 to respond to the plight of the Vietnamese boat people with a mandate of accompaniment, service and advocacy for refugees and other forcibly displaced people (Hampson et al. 2014). In 1994 the Catholic Church in Zambia mandated the JRS to carry out the Church's response to the issues of refugees in the country and JRS began operations in some of the refugee settlements in the country.

Caritas Zambia is another prominent Catholic based organisation whose activities were extended to refugee services. Established in 2001, the mandate of Caritas Zambia was to animate the work of the Catholic Commission for Justice and Peace and the Catholic Commission for Development with the goal of fostering and upholding human dignity through the promotion of human development (ZCCB 2017).

Informed by Merriam (2009) and Yin (2003) that case studies present numerous evidential sources such as documentation, archival records, interviews, direct observations, participant observation and physical artefacts, the study drew on documents and archival records. Documents included annual reports, newspaper articles, photographs and picture stories as guided by Bryman (2004:380-92). These documents were chosen based on the availability (Cohen et al. 2007).

The data were thematically analysed. The thematic analysis was guided by the process outlined by Braun and Clarke (2006: 77-101). It involved the generation and application of codes to the data and the identification, analysis and report of patterns (themes). The thematic approach was used for purposes of understanding the role of the Catholic based organisations in a holistic manner, given that case studies seek to explore phenomena in depth (Creswell 2007).

\section{Catholic Based Organisations' Ways of Addressing Livelihood Challenges of Refugee Youth in Rural Zambia}

The role of Catholic based organisations in addressing the livelihood challenges among the rural refugee youth population was centred on the provision of social services. This included pastoral care, youth empowerment 
activities, social integration, and advocacy, as informed by the teachings of the Catholic Church. These roles therefore revealed how theology could be linked to the experiences of the migrant youth populations and that religious capital underpinned the actions of the Catholic based organisations in addressing the challenges following forced migration.

\section{Pastoral Care}

One prominent role of the Catholic based organisations in addressing the livelihood challenges was the provision of pastoral care. As assigned by the Church, the Catholic based organisations represented the Church by assigning either a clergy, religious or seminarian to accompany them in prayer, sacraments and faith development needs, including the upholding of gospel values (Hibajene 2009). The pastoral care also included counselling services, which were significant to the distressed refugees. For example, the JRS also had a prison initiative that entailed weekly visits to meet with new detainees in order to interview them and determine whether or not they were refugees (Catholic Secretariat 1988). Based on this assessment, JRS then advised them accordingly as to their rights (Hibajene 2009). This was because the social teachings of the Church not only emphasised solidarity with and providing options for the poor (Komakoma 2003), but also the corporal works of mercy especially feeding the hungry, sheltering the homeless, clothing the naked, visiting the sick and the imprisoned and burying the dead (John Paul II 1994). These teachings consisted of the religious capital which facilitated the Catholic based organisations' concern for refugee welfare and thus signified that religion could be a form of capital for engagement through tapping into the teachings or doctrines and values specific to Catholicism (Iannaccone 1990). As Chisale (2016: 4) emphasised, the Church's calling to pastoral care is to empower and liberate the poor, the weak and vulnerable human beings.

Pastoral work was driven by the need to address some of the trauma related challenges faced by the refugees. For example, a 16-year-old refugee fled from his hometown of Moba owing to continuous fighting between the rebel groups and government forces in the DRC.

... an orphan recollects the horrible trek to Zambia as his uncle, his guardian of 10 years was shot dead by unknown forces. 'I ran for my life when my uncle was shot dead while I watched', he says in 
sorrowful voice. 'That is one experience I will never forget for the rest of my life. Hence, I left the country for fear of being caught up' (Syampeyo, Zambia Daily Mail 5 November 2017).

Such experiences highlight the need for addressing not only the spiritual but also the physical needs of the refugee youth, through pastoral care. By responding to the challenges of the refugee youth population through an emphasis on pastoral care, the work of the Catholic based organisations resonated with Bishop Paul Verryn's stance that faith must have a concrete impact on people's lives through transforming reality instead of simply being a plaster or bandage that offers a temporary remedy (Hankela 2014: 198). As such, the role of Catholic based organisations in rural Zambia showed that religious capital in the form of teachings and practices could be utilised in addressing some challenges encountered by the refugee youth populations.

The pastoral role of the Catholic based organisations in addressing the livelihood challenges among the refugee youth population further resonated with the ecclesiological-theological responses and approaches to migration challenges that focused on the practical response from pastoral care that was limited to particular social contexts (Magezi 2017: 4). This was underpinned by calls for the hosting nations and Christians to accommodate migrants (particularly refugees) as well as to stand alongside them as they encounter various challenges.

\section{Youth Empowerment Activities}

Apart from pastoral care, the Catholic based organisations also provided developmental activities with the aim of empowering the refugee youth populations in the rural areas. This was achieved by providing education, skills development and agriculture empowerment. The empowerment initiatives were motivated by the limited access to social services such as education and health care by the refugee youth. As established by Donger et al. (2017), barriers to access education among the refugee youth population included prohibitive costs, lack of adequate educational facilities, challenges of reintegrating into the Zambian education system especially by those who had missed years of schooling during their migration journey, and language. The refugees who did not speak English faced difficulties as English was the de facto language of instruction in secondary and tertiary institutions. While 
legally allowed to attend Zambian schools, refugee school going populations could also be discriminated against or charged significantly higher fees, even in the community-run schools (Frischkorn 2013: 199).

As such, the JRS provided education to the youth in the refugee camps under its care. For example, JRS took up the Maheba refugee settlement camps in the North-Western Province, Mayukwayukwa and Nangwehsi in the Western Province and Ukwimi in the Eastern Province. In addition to these refugee camps, JRS initiated an urban refugee project in 1997, whose aim was to overcome xenophobia which occasionally arose. They achieved this by providing programmes which allowed refugees and citizens to experience positive interaction and treatment of each other (Zambia Episcopal Conference n.d). Given the Catholic stance on education, the youth were provided with holistic education by emphasising that genuine education needed to promote respect for culture, tradition and other values of love, truth, wholeness, justice and freedom (Spaita 2004). Provision of education to the refugee youth population by the Catholic based organisations mirrored the work of the Churches in other contexts, in which education was perceived as a tool for the transformation of the refugee population. For example, Chisale (2016) also linked the liberative role of education from oppression to the education that was provided to the refugee children in South Africa.

Other empowerment initiatives were in agriculture, where youth were encouraged to be entrepreneurial. For example, Caritas focused on input support through revolving funds (farmer group to repay the input costs into common group pool; used for next seasons) at Mantapala refugee settlement in Mansa. The project focused on simple irrigation technologies, seed selection and multiplication. Non-agricultural livelihoods included small livestock, fisheries, beekeeping, food processing, value addition including market linkages and bulking (Filipova 2018). The emphasis on youth empowerment also meant that the refugee youth population experienced employment challenges (Haabazooka et al. 2016), and costs associated with social services including access to reproductive health. As observed by Donger et al. (2017), refugee youth often competed with the poorest locals for the worst jobs and housing and they contended with explicit and de facto barriers to education, healthcare and other services. 'The refugee youth population was seldom consulted and frequently overlooked ... their talents, energy and potential remain largely untapped' (Donger et al. 2017: 4).

The Catholic based organisations consequently sided with the margin- 
alised and the poor, as informed by their social teachings, in ways that sought to improve the livelihoods of the youth population. This also revealed the responsive theology in the context of forced migration. As remarked by the Pope, the notion of Christian welcome and hospitality in the churches, communities and governments was to be applied to all, including migrants and refugees, even those deemed to be illegal (Hampson 2010:20). The Zambian context thus demonstrated that the Catholic based organisations went beyond the provision of a place of refuge for the refugee youth by striving to impart life skills among this group through a contextual theological approach.

In the context of disease, vulnerability and poor access to reproductive healthcare among the refugee youth, JRS established a youth club in Nangweshi camp for young people to attend after school, however, it was mostly utilised by adolescent boys because of cultural factors (Krause et al. 2001). These initiatives were a response to refugee youth's livelihood challenges on limited access to healthcare services. The initiative to offer reproductive health education and services among the refugee youth population was also observed in the work of Bishop Paul Verryn of South Africa, where young people were educated about puberty, sexuality and the dangers and benefits of sexual activity (Chisale 2016:5). As such, the work of Catholic based organisations demonstrated how religion could be capital for addressing the challenges encountered by the refugee youth.

\section{Social Integration}

The Catholic based organisations also had a role of building social integration among the refugee youth population. This was through awareness campaigns (in the form of community talks) that sought to develop a spirit of acceptance between the refugees and the hosting community (Hibajene 2009). At the same time, language lessons and survival skills development training were provided to enable the refugee youth to integrate with the host community. This was supplemented by social events that were organised to facilitate interaction and sharing of ideas and experiences. The Catholic based organisations' initiatives in building social integration were driven by the doctrine of social teachings that encompassed friendliness to humanity (Iannaccone 1990), and this depicted the religious capital embedded in the religious knowledge and doctrine of Catholicism. This role was closely tied to the challenges faced by the refugee youth relating to discrimination, language barriers and social inte- 
gration. For example, a 34-year-old mother of seven recounted the challenge of family break ups owing to forced migration. This highlights the need for deliberate initiatives to integrate the refugee youth population.

My husband has no idea I am in Zambia because I left home abruptly. The conflict became too much hence I decided to take my children and leave the country (Zambia Daily Mail, 5 November 2017).

The Catholic based organisations tapped into their knowledge and doctrines so as to contribute towards addressing the needs of the refugees by facilitating the integration of the youth, not only through language lessons, but by also providing a source of livelihood through educational and agricultural empowerment. In this way, the Catholic based organisations were in solidarity with the refugee youth by way of fostering the mission of the Church through integration. It is also related to the idea that Israel (in the Old Testament) is a paradigm of how native Christians and hosting nations should treat migrants (Matovina \& Tweed 2012: 9; Rivera-Pagán 2012: 580-584). This is because the Catholic based organisations' quest to integrate the refugee youth in the communities was underpinned by the love for one's neighbour, and thus closely related to how Israel was commanded by God to love the foreigners in their land, which in essence was a form of religious capital for migration. As remarked by Bredford-Strohm (2008: 40-41), Israel as a paradigm of how native Christians and hosting nations should treat migrants was a dominating response exhibited in the current migration crisis. As such, the Catholic based organisations' strides to welcome and integrate the refugee youth also affirmed that the religious doctrines of hospitality were a form of capital that facilitated the urgency to address the challenges faced by the refugee youth.

\section{Advocacy}

Further, Catholic based organisations also played an advocacy role for the refugee youth. For example, with a sudden influx of new Angolan refugees who arrived in a newly erected camp, JRS took it upon itself to advocate in a broad sense the refugees' concerns and rights with the camp authorities in Western Zambia. Of importance to the refugees but of low priority to camp and government authorities was the register of those who had died since arriving in Zambia (Hampson et al. 2014). JRS became responsible for keeping a record 
of the dead, on behalf of the living and thereby accompanied the refugees on their journey of life in performing this simple yet meaningful service by way of allowing refugees to formalise the importance of those who had gone before them (Hampson et al. 2014: 8). This was closely related to the Catholic rituals and beliefs that pointed to how the work of the religious organisations was shaped by their religious doctrines as a form of religious capital.

Apart from being informed by weekly visits to prisons, the advocacy role of the Catholic based organisations was also informed by research. For example, JRS was engaged in research on legal issues affecting refugee youth in Zambia, thus informing the proposals for legislation reform (Hibajene 2009). This advocacy role was played through, among other avenues, the national press and radio, including the publication of the Refugee Guide (leaflets with detailed information addressed to refugees and to all those willing to assist them). Ultimately, the engagement of the Catholic organisations was largely driven by the teachings of the Church and the context of the refugee youth. As advanced by Groody (2009: 653), the Church ought to view migration issues from the perspective of God's kingdom. The mission of the Church as the primary basis for reaching out to refugees, was that migrants were the image bearers of God. As such, the target for the Catholic based organisations, were the poor and the marginalised through core programmes in organisational development, gender equality, HIV and AIDS prevention, sustainable agriculture, emergency response and preparedness and governance and human rights (ZCCB 2016).

Ultimately, the Catholic based organisations were making a modest contribution in addressing the challenges faced by the refugee youth. Additionally, religion remained a form of capital for contributing to the welfare of the refugee youth in Zambia. Given that the roles of the Catholic based organisations were closely linked to the provision of social services among the rural refugee youth population, this pointed to how social service provision had remained a concern, worsened by the high levels of poverty and vulnerability characteristic of rural areas (Holmes 2007). As such, there was a need for ongoing interventions that would seek to address the livelihood concerns of the refugee youth population in Zambia.

\section{Conclusion}

The article explored the roles of Catholic based organisations in addressing the 
livelihood challenges faced by the refugee youth population in rural Zambia. The article demonstrated that the roles of the Catholic based organisations were closely related to the challenges of the refugee youth and centred on the provision of social services such as pastoral care, empowerment initiatives, social integration and advocacy. The Catholic based organisations tapped into their religious capital by contributing to the welfare of the refugees through employing humanitarian and developmental approaches, as informed by the social teachings of the Church. Given that the Catholic based organisations were only present in selected refugee camps, these Catholic based organisations were understood to be making a modest contribution to the lives of refugees in rural Zambia. The article also contributes to discourses of religion and forced migration, the perspective that Catholic based organisations in Zambia could be deemed as resourceful in addressing the livelihood challenges faced by the rural refugee youth population.

\section{References}

Adogame, A. 2013. The African Christian Diaspora: New Currents and Emerging Trends in World Christianity. London: Bloomsbury Publishing. Adogame, A. \& C. Weissköppel 2005. Religion in the Context of African Migration. Bayreuth: Breitinger.

Aymer, M. 2015. 'Sojourners' Truths: The New Testament as Diaspora Space.' Journal of the Interdenominational Theological Centre 41,1:1 - 18.

Becker, S.O. \& A. Ferrara 2019. 'Consequences of Forced Migration: A Survey of recent Findings.' Labour Economics 59:1-16.

https://doi.org/10.1016/j.labeco.2019.02.007

Bourdieu, P. 1986. The Forms of Capital. In Sadovnik, A.R. (ed.): Sociology of Education: A Critical Reader. New York: Routledge.

Braun, V. \& V. Clarke 2006. Using Thematic Analysis in Psychology. Qualitative Research in Psychology 3,2: 77 - 101.

https://doi.org/10.1191/1478088706qp063oa

Bredford-Strohm, H. 2008. Responding to the Challenges of Migration and Flight from a Perspective of Theological Ethics. Brussels: Churches' Commission for Migrants in Europe.

Bryman, A. 2004. Social Research Methods. Oxford: Oxford University Press. Carmona, M.S. 2010. Report of Independent Expert on the Question of Human Rights and Extreme Poverty. Human Rights Council, May 11. 
Catholic Secretariat 1988. The Work of the Catholic Church in Refugee and Relief Work in Zambia. The Voice of Refugees 23: 1 - 9.

Chisale, S.S. 2016. Bishop Paul Verryn's Pastoral Response towards Unaccompanied Refugee Minors. HTS Teologiese Studies/Theological Studies 72,2:1 - 8. https://doi.org/10.4102/hts.v72i2.3411

Cohen, L., L. Manion \& K. Morrison 2007. Research Methods in Education. London: Routledge Falmer.

https://doi.org/10.4324/9780203029053

Collet, B.A. 2011. Religion, Forced Migration and Schooling: Varying Influences in Jordan and the USA. Power and Education 3,3: 274 - 288. https://doi.org/10.2304/power.2011.3.3.274

Creswell, J.W. 2007. Qualitative Inquiry and Research Design. London: Sage Publications.

Donger, E., J. Leigh, A. Fuller \& J. Leaning 2017. Refugee Youth in Lusaka: A Comprehensive Evaluation of Health and Wellbeing. UNCHR: Centre for Health and Human Rights.

Filipova, Z. 2018. Refugee Assessment Luapula Province, Zambia Report. Zambia.

Frischkorn, R.S. 2013. We Just Aren't Free: Urban Refugees and Integration in Lusaka, Zambia. PhD dissertation. American University, Washington DC.

Government of the Republic of Zambia 1970. The Refugees (Control) Act 1970. Lusaka: GRZ.

Groody, D. G 2009. Crossing the Divide: Foundations of a Theology of Migration and Refugees. Theological Studies 70,3: 638 - 667.

https://doi.org/10.1177/004056390907000306

Haabazoka, L., P.S. Kamanga, C. Sichinsambwe \& S. Kapena 2016. A Study of the Challenges of Youth Employment in Zambia. International Journal of Commerce and Management Research 2,6: 41 - 46.

Hagan, J. \& H.R. Ebaugh 2003. Calling upon the Sacred: Migrants' Use of Religion in the Migration Process. International Migration Review 37,4: 1145 - 1162. https://doi.org/10.1111/j.1747-7379.2003.tb00173.x

Hampson, J. 2010. JRS Accompaniment - A New Way of Being Present? Grace \& Truth: A Journal of Catholic Reflection of Southern Africa 27,2: $15-28$.

Hampson, J., T.M. Crea, R. Calvo \& F. Alvarez 2014. The Value of Accompaniment. Forced Migration Review 48: 7 - 8. 
Hanciles, J. 2008. Beyond Christendom: Globalisation, African Migration, and the Transformation of the West. Maryknoll: Orbis Books.

Hankela, E. 2014. Ubuntu, Migration and Ministry: Being Human in a Johannesburg Church. Leiden: Brill.

https://doi.org/10.1163/9789004274136

Hibajene, F. 2009. People on the Move. Caritas Zambia: Pontifical Council for the Pastoral Care of Migrants and Itinerant People.

Holmes, R. 2007. Social Protection and Low Capacity Households in Zambia. Social Protection Report, Linking Social Protection and Agricultural Growth Series.

Hoover, S.M. 2012. Religion and the Media in the $21^{\text {st }}$ Century. Paper presented at a Conference on Media, Diversity, and Religious Freedom. Auditori de la Facultat de Comunicació Blanquerna, Universitat Ramon Llull.

Innanaccone, L. 1990. Religious Practice: A Human Capital Approach. Journal for the Scientific Study of Religion 29: 297 - 314.

https://doi.org/10.2307/1386460

Komakoma, J. 2003. The Social Teaching of the Catholic Bishops and Other Christian Leaders in Zambia: Major Pastoral Letters and Statements 1953-2001. Ndola: Mission Press.

Krause, S.M., J. Meyers \& J.M. Mutambo 2001. Assessment of Reproductive Health for Refugees in Zambia. Women's Commission for Refugee Women and Children.

Magezi, C. 2017. Migration Crisis and the Church: A Response to Lacunae and Considerations for Christian Ministry Engagement. Verbum et Ecclesia 38,1: 1 - 9. https://doi.org/10.4102/ve.v38i1.1671

Matovina, T. \& T. Tweed 2012. Migration Matters: Perspective from Theology and Religious Studies. Apuntes 32,1: 4 - 20.

Merriam, S.B. 2009. Qualitative Research: A Guide to Design and Implementation. San Francisco: Jossey-Bass.

Mouton, J. 2001. How to Succeed in your Master's and Doctoral Studies: A South African Guide and Resource Book. Pretoria: Van Schaick Publishers.

Mwale, N. 2013. Religion and Development in Zambia: The Role of the Roman Catholic Church in the Political Development of Zambia: 18901964. Alternation Special Edition 11: 110 - 133.

http://alternation.ukzn.ac.za/Files/docs/20.8/05\%20Mwa.pdf 
Mwale, N. \& J. Chita 2017. 'The Catholic's Social Responsibility in Zambia: The Catholic Response to the 2016 Prejudiced Attacks on 'Others'. Alternation Journal Special Edition 19: 132 - 156. https://doi.org/10.29086/2519-5476/2017/sp19a6

Myers, M.D. 2009. Qualitative Research in Business and Management. London: Sage.

Nyamazana, M., G. Koyi \& E. Chibili 2017. Zambia Refugees Economies: Livelihoods and Challenges. Institute of Economic and Social Research, University of Zambia and Refugees Studies Centre, University of Oxford. Nzayabino, V. 2005. The Role of Refugee-established Churches in the Lives of Forced Migrants: A Case Study of Word of Life Assembly in Yeoville, Johannesburg. A Research report submitted to the Faculty of Arts, University of Witwatersrand, Johannesburg. https://doi.org/10.4102/hts.v66i1.290

Nzayabino, V. 2010. The Role of Refugee-established Churches in Integrating Forced Migrants: A Case Study of Word of Life Assembly in Yeoville, Johannesburg. HTS Theological Studies 66,1: 1 - 9.

Paul II, Pope John 1994. Catechism of the Catholic Church. London: Geoffrey Chapman.

Rivera-Pagán, L.N. 2012. Xenophilia or Xenophobia: Towards a Theological Migration. The Ecumenical Review 64,4: 575 - 589.

https://doi.org/10.1111/erev.12013

Schreiter, R. 2009. Spaces for Religion and Migrants Religious Identity. Forum Mission 5: 155 - 171.

Settler, F. 2018. A Postcolonial Perspective of Religion and Migration. In Machado, D., B. Turner \& T. Wyller (eds.): Borderland Religion: Ambiguous Practices of Difference, Hope and Beyond. Abingdon: Routledge.

https://doi.org/10.4324/9781351056946-8

Settler, F. \& B. Mpofu 2017. Social Responsibility with Respect to Religion and Migration in South Africa. Journal for the Study of Religion 30,2: 12 - 31. http://www.scielo.org.za/pdf/jsr/v30n2/02.pdf; https://doi.org/10.17159/2413-3027/2017/v30n2a1

Sommers, M. 2001. Young, Male and Pentecostal: Urban Refugees in Dar es

Salaam, Tanzania. Journal of Refugee Studies 14,4: 347 - 370.

https://doi.org/10.1093/jrs/14.4.347

Spaita, J.M. 2014. Interview with the Post Newspaper, 26 August. 
Syampeyo, Y. 2017. Tales of Refugees in Nchelenge. Zambia Daily Mail. 5 November.

Ter Haar, G. \& S. Ellis 2006. The Role of Religion in Development: Towards

a New Relationship Between the European Union and Africa. The European Journal of Development Research 18,3: 351 - 67.

https://doi.org/10.1080/09578810600893403

Ter Haar, G. \& J.B. Busuttil 2005. Bridge or Barrier: Religion, Violence, and Visions for Peace. Leiden: Brill.

United Nations High Commissioner for Refugees 2017. Operational Portal, June.

United Nations High Commissioner for Refugees 2018. Operational Portal, June.

Sommers, M. 2001. Young, Male and Pentecostal: Urban Refugees in Dar es Salaam, Tanzania. Journal of Refugee Studies 14,4: 347 - 370.

United Nations High Commissioner for Refugees 2019. 1969 OAU Refugee

Convention. Fact Sheet. https://www.unhcr.org/5cd569744.pdf

(Accessed on 16 November 2020.)

Verter, B. 2003. Spiritual Capital: Theorising Religion with Bourdieu against

Bourdieu. Sociological Theory 21,2: 150 - 174.

https://doi.org/10.1111/1467-9558.00182

Yin, R. 2003. Case Study Research: Design and Methods. London: Sage Publishers.

Zambia Conference of Catholic Bishops (ZCCB) 2017. Annual Report - 2017. Unpublished manuscript.

Zambia Conference of Catholic Bishops. 2016. Strategic Plan 2017 - 2026. Lusaka: ZCCB Archives.

Zambia Episcopal Conference (ZEC) n.d. Refugee Service Report. Unpublished manuscript. ZEC Archives.

Nelly Mwale Department of Religious Studies University of Zambia

Research Fellow Research Institute for Theology and Religion University of South Africa nelmwa@gmail.com 